
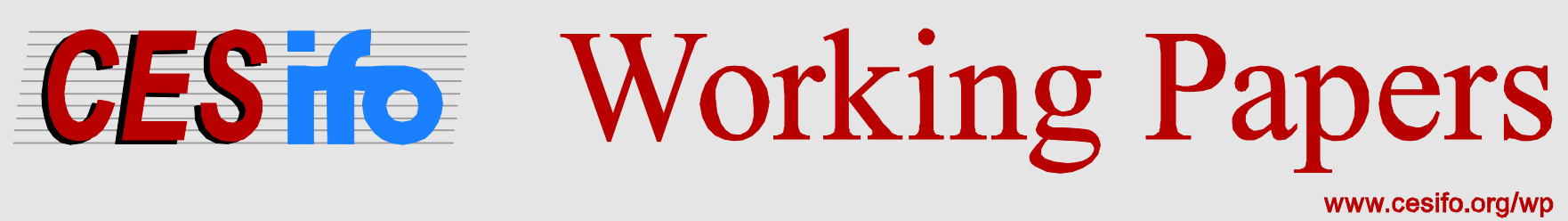

\title{
Dynamic Entry and Exit Linkages in the Brazilian Manufacturing Industry: An Econometric Investigation
}

\author{
Marcelo Resende \\ Eduardo P. Ribeiro \\ Rodrigo M. Zeidan
}

CESIFO WORKING PAPER NO. 4209

CATEGORY 11: INDUSTRIAL ORGANISATION APRIL 2013
An electronic version of the paper may be downloaded
- from the SSRN website:
- from the RePEc website:
- from the CESifo website:
www.SSRN.com
www.RePEc.org
www.CESifo-group.org/wp

\section{CESifo}




\title{
Dynamic Entry and Exit Linkages in the Brazilian Manufacturing Industry: An Econometric Investigation
}

\begin{abstract}
The paper investigates dynamic linkages between entry and exit rates in Brazilian manufacturing in the context of 231 (4-digits) industries during the 1996-2005 period. The empirical analysis focuses on the estimation of a dynamic panel data for entry and exit rates and controls for the business cycle. The empirical evidence is consistent with a multiplier effect where synergetic factors prevail either by entry inducing entry or by exit inducing exit. Evidence partially supports a competition effect that could be related to a selection process favouring efficiency, as exit induces entry. The business cycle control variable appears to play no role. The results are similar, though not identical to previous evidence for developed countries.
\end{abstract}

JEL-Code: L100, C330.

Keywords: entry and exit rates, dynamic panel data.

\author{
Marcelo Resende \\ Economic Institute \\ Federal University of Rio de Janeiro \\ Av. Pasteur 250, Urca, 22290-240 \\ Rio de Janeiro-RJ / Brazil \\ mresende@ie.ufrj.br
}

Eduardo P. Ribeiro

Economic Institute

Federal University of Rio de Janeiro

Av. Pasteur 250, Urca, 22290-240

Rio de Janeiro-RJ / Brazil

eribeiro@ie.ufrj.br
Rodrigo M. Zeidan

Fundaçäo Dom Cabral and

Nottingham University Business School

University of Nottingham, Ningbo (UNNC)

199 Taikang East Road, Ningbo, 315100 /

PR China

rodrigo.zeidan@nottingham.edu.cn

The authors acknowledge the research assistance from Pamela Encarnação. Marcelo Resende is grateful for the funding from CNPq. 


\section{Introduction}

Perfect mobility of economic agents with respect to a market is an idealized assumption that is important to enable a long-run competitive equilibrium. Most notably, non-negligible entry rates are likely to play an important role in eroding abnormal profits in the absence of substantial barriers to entry. ${ }^{1}$ Nevertheless, it is important to stress that the presence of significant sunk costs in particular industries may thwart exit and therefore induce more cautious entry flows. This last remark underscores the possibility of the emergence of different intertemporal linkages between entry and exit rates.

In recent years, some empirical regularities regarding entry patterns appear to have emerged as indicated by Dunne and Roberts (1991) and Geroski (1991, 1995). The former emphasized the substantial heterogeneity of entry patterns in the U.S, manufacturing industry. In the case of less developed economies, studies on industry dynamics are somewhat incipient. Campos and lootty (2006) on selected manufacturing industries and Façanha and Resende (2004) on a multisector study are two exceptions. The evidence from the latter suggested a substantial degree of heterogeneity in average plant size, and entry and exit rates across industries, which was consistent with previous results for the U.S.

Brazilian manufacturing can provide an interesting ground for additional studies on industry dynamics. In fact, that large emerging economy is characterized by the co-existence of both traditional and technologically dynamic sectors. In addition, we take advantage of a unique data set for Brazil, which covers firms of all sizes in a longitudinal dimension. In general, yearly data sets based on statistical office surveys impose a lower size threshold on the sampling frame. Measuring entry

\footnotetext{
${ }^{1}$ A related topic pertains to the literature on profit persistence as exemplified by Resende (2006) in the case of Brazil.
} 
and exit may imply not only de facto business openings and closing but also threshold crossings.

It appears therefore that the gap in the empirical literature could be fruitfully explored in terms of a relatively neglected topic concerning the dynamic interdependencies between entry and exit rates. Previous works along that line include Johnson and Parker (1994), Kangasharju and Moisio (1998) and Nyström (2007). The latter highlights two kinds of effects that can establish linkages between entry and exit rates. First, a competition effect may indicate that past entry induces exit and lowers entry, given pressures exerted by relatively more efficient firms. The competition effect is associated with past exit favouring entry and lowering exit rates. Second, a multiplier effect according to which entry might foster additional future entry (and lower exit rates) as the benefits from agglomerations can be compelling. A multiplier effect of exit rates implies higher exit rates and lower entry rates, as higher exit rates indicate worse economic conditions. Previous evidence for Sweden appears to indicate the prevalence of both types of effects.

Competition and multiplier effects can be tested by assessing the influence of coefficients related to lagged variables. However, it is important not to impose strict exogeneity assumptions and throughout the present application we assume that the explanatory variables are predetermined only.

The present paper aims at contributing to the literature in at least four aspects:

a) There is a clear gap in terms of related studies for developing countries;

b) The detailed plant-level data used for obtaining the entry and exit rates in the present study are not subject to the shortcomings of a previous study where indicators relied on plant and firm level data that were concatenated; 
c) We control for the business cycle that can potentially affect the dynamic linkages between entry and exit;

d) We explore the implications of exogeneity assumptions.

Advancing the results, the competition and multiplier effects appear relevant for the entry rates while the exit rates reveal a multiplier effect but not significant competition effects.

The paper is organized as follows: the second section discusses motivations for the different dynamic linkages between entry and exit rates and overviews the econometric framework. The third section discusses the data and presents the descriptive and econometric results. The fourth and final section adds some final comments.

\section{Entry and Exit Linkages}

\section{1- Conceptual aspects}

Economists have extensively studied the determinants of firms' survival and the patterns of entry and exit. Theoretical models find a wide range of explanations for the relationship between entry and exit in different industries. Hopenhayn (1992) presents a stochastic model in which entry and exit are part of the limiting behaviour of the industry and not only part of the adjustment to a steady state, while the model by Jovanovic and Lach (1989) results in staggered entry and exit related to the learning curve of entrants. Agarwal and Gort (1996) explore the role of the product cycle and show that entry rates are affected by stage-related changes in both the rate of technical advance and the form that innovations take, while exit is determined largely by stage-related changes in the intensity of competition, which is the same result as in Klepper 
(1996). Recently, Pakes et al. have provided a model based on dynamic discrete games that is taken by Dunne et al (2011), and that results in three main determinants of entry and exit: the toughness of short-term competition, the magnitude of the sunk cost of entry by potential entrants, and the magnitude of fixed costs faced by incumbent producers.

There is a substantial empirical literature on entry and exit, with results for many countries, such as the United States (Dunne et al, 1998 and Dunne and Roberts, 1991), the United Kingdom (Disney et al, 2003), and Canada (Baldwin and Gorecki, 1991). The present paper follows the literature that explains the patterns of births and deaths through two main effects, the competition and multiplier effects. Johnson and Parker (1994) are the first to recognize these two distinct forces, and their work is then taken up by Nystrom (2007) and Manjon-Antolin (2010).

The multiplier effect is related to the concept of network externalities, and means that the entrance of a firm increases the probability of other firms entering the market. The argument for the multiplier effect is simple: market entrance signals market opportunities to other firms, and creates economies of scale based on the size of the market, one of the main reasons for clustering.

The competition effect relates entrance to future exit by a simple mechanism: new firms may be more innovative and disrupt the market, causing fringe inefficient incumbents to exit, either because of new products (relating it to the product life cycle theory); or because of differences in production costs.

Because both effects occur simultaneously, there is interdependence between entry and exit, and the literature is well established in finding evidence of such 
phenomena, comparing patterns either in different regions or across industrial sectors.

However, there is one important feature of the interdependence between exit and entry that it is missing in the recent empirical literature: the impact of the business cycle on the patterns of entry and exit, as in Campbell (1988). The model relates entry and exit patterns to shocks to the rate of embodied technological progress, thus presenting another rationale for observable patterns other than the multiplier and competition effects.

The features of the business cycle would exert an impact on the patterns of entry and exit due to technological advances. The result is that the increase in the aggregate exit rate would be followed by increases in entry, productivity, and output as new plants embodying the innovation become productive. The model economy would reproduce the cyclical features of the entry and exit data: Exit would be countercyclical and would lead to output and productivity growth, which both accompany entry. Thus, if we do not control for the business cycle there is no way to distinguish if the patterns of exit and entry are due to the interdependence caused by the multiplier and competition effects, or by the natural cycle of technological shocks as in Campbell (1988).

We then build on the literature by improving the estimation and the accuracy in the search for better evidence of entry and exit patterns, and account for the business cycle.

Usually the search for these effects is based on the expected signs for the multiplier and competition effects.

If one assumes that both entry and exit are a function of previous entry and exit, the expected signs for the multiplier and competition effects are simple. 
If we can disentangle the data to extract the multiplier and competition effects we should observe that the multiplier effect would cause previous entry to increase entry, the converse being true for exit. As for the competition effect, we should observe that previous entry would cause a higher exit rate, with the converse also being true. Table 1 provides a summary of relevant expected signs associated to the different effects.

Table 1 - expected signs for the multiplier and competition effects.

\begin{tabular}{|l|c|c|}
\hline & Multiplier & Competition \\
\hline Entry/previous entry & + & - \\
\hline Exit/previous exit & + & - \\
\hline Entry/previous exit & - & + \\
\hline Exit/previous entry & - & + \\
\hline
\end{tabular}

Source: Nystrom (2007)

\section{2- Econometric framework}

The present paper aims to access the dynamic linkages between entry and exit. Following the literature, we specify a vector autoregression model for both entry $(y)$ and exit $(x)$ rates, but using a panel data fixed effect structure:

$$
\begin{aligned}
& y_{i t}=\alpha_{11} y_{i, t-1}+\beta_{11} x_{i t-1}+\mu_{y_{i}}+v_{i t} \\
& x_{i t}=\alpha_{21} y_{i, t-1}+\beta_{21} x_{i t-1}+\mu_{x i}+w_{i t}
\end{aligned}
$$

where $\mu_{x i}$ and $\mu_{y i}$ are fixed effects that capture sector time invariant heterogeneity and $v_{i t}$ and $w_{i t}$ unobserved terms, contemporaneously uncorrelated with the explanatory variables ${ }^{2}$. The model could also include time effects $\left(\lambda_{y_{t}}\right.$ and $\left.\lambda_{x t}\right)$

\footnotetext{
${ }^{2}$ We use one lag for the explanatory variables for model description pourposes. Further lags are possible and are indeed considered in the empirical application.
} 
that capture non-observed heterogeneities that only depend on the time period and typically are considered by period dummy variables.

Our empirical strategy uses a panel of sectors, instead of a pure time series analysis. There are no long time series of entry and exit rates in general (see the literature review above), particularly in developing countries. A dynamic panel data structure motivates panel data estimators that avoid biases from traditional estimators [see e.g. Baltagi (2001) and Cameron and Trivedi (2010)], such as the well-known Arellano and Bond - AB (1991) estimator. This is a generalized method of moment-GMM estimator that uses an orthogonality condition on the appropriate instruments and the error (henceforth GMM-DIF) on the first difference of the above equations, so as to eliminate the fixed effects.

It can be verified that lagged dependent variables are appropriate instruments for $\Delta y_{i, t-1}$, starting with $y_{i 1}$ at $\mathrm{T}=3, y_{i 1}$ and $y_{i 2}$ at $\mathrm{T}=4$ up to $y_{i 1}, \ldots, y_{i, T-2}$ for $\mathrm{T}$. The remaining elements of the instrument matrix will depend on the assumptions regarding additional regressors $x_{i t-1}$. In the simplest case where they are assumed to be strictly exogenous (uncorrelated with past, current and future errors) the variables can be readily used as instruments whereas in the case of weak exogeneity, the $x_{i t-1}$ regressors are treated as $y_{i t-1}$. The validity of the instruments is important for the consistency of the GMM-DIF estimator. It can be evaluated using the Sargan test for overidentifying restrictions. It is important to restrict the number of instruments so as to assure good power properties for the Sargan test. Additionally, the possible validity of lags as instruments hinges on the presence of serial correlation. Due to the GMM estimation, we use the autocorrelation tests suggested by $A B$. 
We assume that all right-hand side variables are weakly exogenous (predetermined), as it is a weaker assumption than strict exogeneity. This is a point overlooked in the empirical literature.

In a structural time series context (see e.g., Johnston and DiNardo, 1994), the linear regression based on expressions (1) and (1') are actually reduced form models, as no contemporaneous values of the explanatory variable are used in the test regression. In this structural model, Granger non-causality from, say, $y$ to $x$, is observed when the $y$ variable is not contemporaneously correlated with $x$ and does not feedback (past values of $y_{t}$ are uncorrelated with $x_{t}$ ). What has been overlooked in the literature is that in the linear panel data model (2) Granger noncausality from $y$ to $x$ requires the $x$ variables can be considered as strictly exogenous in the regression with $y$ as dependent variable. In other words, exogeneity assumptions in a Granger causality test regression using panel data are actually reverse Granger causality statements. As we do not want to impose a priori assumptions on reverse Granger causality, we assume that the explanatory variables are only weakly exogenous in the regressions below.

\section{Empirical Analysis}

\section{1- Data source}

The basic data source was the Relação Anual de Informações Sociais-RAIS [Ministry of Labour and Employment, Brazil]. This administrative survey has the character of a census and collects information on the number of employees and their educational characteristics at the plant level in formal establishments. This is a unique data set that can be used for measuring entry and exit rates as it covers firms of all employee sizes, contrary to the official statistical office manufacturing 
survey and allows firms to be followed over time, from opening to closing. Annual manufacturing surveys (such as the Brazilian PIA), have a minimum firm size for sampling. Entry and exit rates based on these data therefore include firm openings and closing as well as firms crossing the sampling size threshold. This is a limitation in many data sets, such as Nystrom (2007). Dunne and Roberts (1991) do use census data, but for five year intervals.

In this paper, we have focused on 4-digits sectors of the Brazilian manufacturing industry over the $1995-2005$ period. We have been granted special access to identified microdata that allowed us to compute sector-level entry and exit rates for the 1996-2005 period. Entry or exit can be identified by comparing the unique identifier between adjacent periods, namely the numerical identifier (CNPJ) where the first digits (the root of the code) refer to the firm and the remaining digits to a specific plant.

Relevant descriptive statistics are reported in Table 2 where one observes significant heterogeneity across sectors and over time. Average entry rates vary from $23 \%$ to $15,9 \%$, while average exit rates vary between $19,2 \%$ and $12,6 \%$. The possibility of the business cycle affecting the dynamic relationship between entry and exit rates motivates the control for real sales. This sector variable is obtained from the Pesquisa Industrial Anual-PIA-IBGE [net operational revenues deflated by the consumer price index (IPCA-IBGE)]. The balanced panel consists of 231 (4-digits) sectors over the 1996-2005 period.

\section{2- Empirical results}

The econometric results for the entry and exit equations are reported in Tables 3 and 4 , respectively. Table 5 reports related joint significance tests. 
Table 2

Summary Statistics - Entry and Exit Rates in the Brazilian Manufacturing -19962005 [231 (4-digits) sectors]

\begin{tabular}{|l|c|c|c|c|c|c|}
\hline \multicolumn{7}{|c|}{ Entry rates } \\
\hline Year & Mean & Std. dev. & Min. & Max. & Skewness & Kurtosis \\
\hline $\mathbf{1 9 9 6}$ & 0.196 & 0.073 & 0.043 & 0.537 & 1.192 & 6.057 \\
\hline $\mathbf{1 9 9 7}$ & 0.230 & 0.077 & 0.062 & 0.484 & 0.308 & 3.024 \\
\hline $\mathbf{1 9 9 8}$ & 0.182 & 0.062 & 0.040 & 0.426 & 0.500 & 3.771 \\
\hline $\mathbf{1 9 9 9}$ & 0.182 & 0.066 & 0.011 & 0.566 & 1.151 & 8.244 \\
\hline $\mathbf{2 0 0 0}$ & 0.205 & 0.071 & 0.040 & 0.545 & 1.566 & 7.938 \\
\hline $\mathbf{2 0 0 1}$ & 0.181 & 0.063 & 0.041 & 0.510 & 1.250 & 6.971 \\
\hline $\mathbf{2 0 0 2}$ & 0.169 & 0.054 & 0.043 & 0.351 & 0.500 & 3.536 \\
\hline $\mathbf{2 0 0 3}$ & 0.160 & 0.055 & 0.037 & 0.382 & 0.951 & 4.967 \\
\hline $\mathbf{2 0 0 4}$ & 0.166 & 0.071 & 0.024 & 0.590 & 2.451 & 13.819 \\
\hline $\mathbf{2 0 0 5}$ & 0.159 & 0.063 & 0.028 & 0.482 & 1.733 & 8.251 \\
\hline \multicolumn{7}{|c|}{ Exit Rates } \\
\hline Year & Mean & Std. dev. & Min. & Max. & Skewness & Kurtosis \\
\hline $\mathbf{1 9 9 6}$ & 0.192 & 0.066 & 0 & 0.529 & 1.142 & 6.494 \\
\hline $\mathbf{1 9 9 7}$ & 0.186 & 0.060 & 0.030 & 0.402 & 0.998 & 4.536 \\
\hline $\mathbf{1 9 9 8}$ & 0.175 & 0.054 & 0.031 & 0.453 & 0.956 & 6.348 \\
\hline $\mathbf{1 9 9 9}$ & 0.167 & 0.057 & 0 & 0.435 & 1.118 & 6.826 \\
\hline $\mathbf{2 0 0 0}$ & 0.170 & 0.064 & 0 & 0.476 & 1.368 & 6.532 \\
\hline $\mathbf{2 0 0 1}$ & 0.149 & 0.054 & 0 & 0.469 & 1.756 & 10.217 \\
\hline $\mathbf{2 0 0 2}$ & 0.139 & 0.045 & 0 & 0.354 & 1.056 & 6.615 \\
\hline $\mathbf{2 0 0 3}$ & 0.147 & 0.052 & 0.043 & 0.421 & 1.416 & 6.787 \\
\hline $\mathbf{2 0 0 4}$ & 0.126 & 0.040 & 0.045 & 0.341 & 0.846 & 6.266 \\
\hline $\mathbf{2 0 0 5}$ & 0.131 & 0.048 & 0.029 & 0.450 & 1.890 & 11.444 \\
\hline
\end{tabular}


Table 3

Results from GMM-DIF estimation (two-steps estimation)

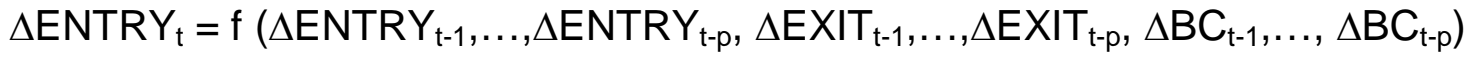

\begin{tabular}{|c|c|c|c|}
\hline \multirow[t]{2}{*}{ Regressors } & \multicolumn{3}{|c|}{ Dependent variable: $\triangle E N T R Y$} \\
\hline & $p=1$ & $p=2$ & $p=3$ \\
\hline Constant & $\begin{array}{l}-0.213 \\
(0.408)\end{array}$ & $\begin{array}{l}-0.122 \\
(0.759)\end{array}$ & $\begin{array}{l}-0.128 \\
(0.850)\end{array}$ \\
\hline$\Delta$ ENTRY $_{-1}$ & $\begin{array}{c}0.138 \\
(0.001)\end{array}$ & $\begin{array}{c}0.056 \\
(0.261) \\
\end{array}$ & $\begin{array}{c}0.122 \\
(0.067) \\
\end{array}$ \\
\hline$\Delta$ ENTRY $_{-2}$ & - & $\begin{array}{l}-0.039 \\
(0.260) \\
\end{array}$ & $\begin{array}{l}-0.015 \\
(0.702) \\
\end{array}$ \\
\hline$\Delta$ ENTRY $_{-3}$ & - & - & $\begin{array}{c}0.034 \\
(0.443)\end{array}$ \\
\hline$\Delta \mathrm{EXIT}_{-1}$ & $\begin{array}{c}0.162 \\
(0.000) \\
\end{array}$ & $\begin{array}{c}0.128 \\
(0.427) \\
\end{array}$ & $\begin{array}{c}0.304 \\
(0.074) \\
\end{array}$ \\
\hline$\Delta \mathrm{EXIT}_{-2}$ & - & $\begin{array}{c}0.003 \\
(0.947) \\
\end{array}$ & $\begin{array}{c}0.122 \\
(0.262) \\
\end{array}$ \\
\hline$\Delta \mathrm{EXIT}_{-3}$ & - & - & $\begin{array}{c}0.038 \\
(0.457) \\
\end{array}$ \\
\hline$\Delta B_{-1}$ & $\begin{array}{c}0.027 \\
(0.133) \\
\end{array}$ & $\begin{array}{c}0,038 \\
(0.152) \\
\end{array}$ & $\begin{array}{c}0.072 \\
(0.011) \\
\end{array}$ \\
\hline$\Delta \mathrm{BC}_{-2}$ & - & $\begin{array}{l}-0.020 \\
(0.342) \\
\end{array}$ & $\begin{array}{l}-0.071 \\
(0.049) \\
\end{array}$ \\
\hline$\Delta \mathrm{BC}_{-3}$ & - & - & $\begin{array}{c}0.014 \\
(0.642) \\
\end{array}$ \\
\hline D1998 & $\begin{array}{l}-0.052 \\
(0.000)\end{array}$ & - & - \\
\hline D1999 & $\begin{array}{l}-0.041 \\
(0.000) \\
\end{array}$ & $\begin{array}{c}0.024 \\
(0.162) \\
\end{array}$ & - \\
\hline D2000 & $\begin{array}{l}-0.026 \\
(0.000)\end{array}$ & $\begin{array}{c}0.031 \\
(0.071)\end{array}$ & $\begin{array}{c}0.011 \\
(0.144)\end{array}$ \\
\hline D2001 & $\begin{array}{l}-0.053 \\
(0.000)\end{array}$ & $\begin{array}{c}0.045 \\
(0.002)\end{array}$ & $\begin{array}{l}-0.010 \\
(0.226)\end{array}$ \\
\hline D2002 & $\begin{array}{l}-0.057 \\
(0.000)\end{array}$ & $\begin{array}{c}0.020 \\
(0.104)\end{array}$ & $\begin{array}{l}-0.011 \\
(0.417) \\
\end{array}$ \\
\hline D2003 & $\begin{array}{l}-0.066 \\
(0.000)\end{array}$ & $\begin{array}{c}0.015 \\
(0.079)\end{array}$ & $\begin{array}{l}-0.015 \\
(0.417)\end{array}$ \\
\hline D2004 & $\begin{array}{l}-0.060 \\
(0.000) \\
\end{array}$ & $\begin{array}{c}0.004 \\
(0.374) \\
\end{array}$ & $\begin{array}{l}-0.007 \\
(0.757) \\
\end{array}$ \\
\hline D2005 & $\begin{array}{l}-0.069 \\
(0.000)\end{array}$ & $\begin{array}{c}0.010 \\
(0.058)\end{array}$ & $\begin{array}{l}-0.017 \\
(0.527)\end{array}$ \\
\hline Sargan test & $\begin{array}{l}\chi^{2}(60)=63.256 \\
(0.362)\end{array}$ & $\begin{array}{l}\chi^{2}(50)=46.643 \\
(0.609)\end{array}$ & $\begin{array}{l}\chi^{2}(50)=47.819 \\
(0.561)\end{array}$ \\
\hline AR(1) test & $\begin{array}{l}-6.780 \\
(0.000)\end{array}$ & $\begin{array}{l}-6.137 \\
(0.000)\end{array}$ & $\begin{array}{l}-4.764 \\
(0.000)\end{array}$ \\
\hline AR(2) test & $\begin{array}{l}-0.156 \\
(0.876)\end{array}$ & $\begin{array}{c}0.495 \\
(0.621)\end{array}$ & $\begin{array}{c}0.846 \\
(0.397)\end{array}$ \\
\hline
\end{tabular}

Note: $p$-values are indicated in parentheses 
Table 4

Results from GMM-DIF estimation (two-steps estimation)

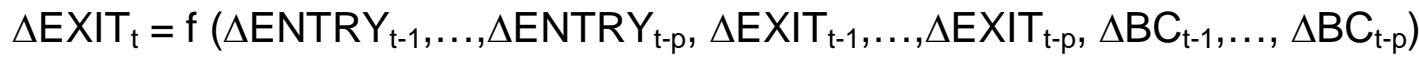

\begin{tabular}{|c|c|c|c|}
\hline \multirow[t]{2}{*}{ Regressors } & \multicolumn{3}{|c|}{ Dependent variable: $\Delta E X I T$} \\
\hline & $p=1$ & $p=2$ & $p=3$ \\
\hline Constant & $\begin{array}{c}0.049 \\
(0.399)\end{array}$ & $\begin{array}{l}-0.159 \\
(0.053)\end{array}$ & $\begin{array}{l}-0.636 \\
(0.174)\end{array}$ \\
\hline$\Delta \mathrm{EXIT}_{-1}$ & $\begin{array}{c}0.100 \\
(0.010)\end{array}$ & $\begin{array}{c}0.072 \\
(0.202)\end{array}$ & $\begin{array}{c}0.047 \\
(0.637)\end{array}$ \\
\hline$\Delta \mathrm{EXIT}_{-2}$ & - & $\begin{array}{l}-0.007 \\
(0.852) \\
\end{array}$ & $\begin{array}{c}0.030 \\
(0.607) \\
\end{array}$ \\
\hline$\Delta \mathrm{EXIT}_{-3}$ & - & - & $\begin{array}{c}0.061 \\
(0.158)\end{array}$ \\
\hline$\Delta$ ENTRY $_{-1}$ & $\begin{array}{c}0.058 \\
(0.139)\end{array}$ & $\begin{array}{c}0.104 \\
(0.472)\end{array}$ & $\begin{array}{c}0.196 \\
(0.214)\end{array}$ \\
\hline$\Delta$ ENTRY $_{-2}$ & - & $\begin{array}{c}0.019 \\
(0.600)\end{array}$ & $\begin{array}{l}-0.099 \\
(0.426) \\
\end{array}$ \\
\hline$\Delta$ ENTRY $_{-3}$ & - & - & $\begin{array}{c}0.004 \\
(0.921)\end{array}$ \\
\hline$\Delta \mathrm{BC}_{-1}$ & $\begin{array}{c}0.007 \\
(0.083)\end{array}$ & $\begin{array}{c}0.008 \\
(0.062)\end{array}$ & $\begin{array}{c}0.038 \\
(0.097)\end{array}$ \\
\hline$\Delta B_{-2}$ & - & $\begin{array}{c}0.010 \\
(0.048)\end{array}$ & $\begin{array}{c}0.030 \\
(0,244)\end{array}$ \\
\hline$\Delta \mathrm{BC}_{-3}$ & - & - & $\begin{array}{l}-0.014 \\
(0.433) \\
\end{array}$ \\
\hline D1998 & $\begin{array}{l}-0.008 \\
(0.055) \\
\end{array}$ & - & - \\
\hline D1999 & $\begin{array}{l}-0.014 \\
(0.000)\end{array}$ & $\begin{array}{c}0.042 \\
(0.000)\end{array}$ & - \\
\hline D2000 & $\begin{array}{l}-0.011 \\
(0.002)\end{array}$ & $\begin{array}{c}0.036 \\
(0.000)\end{array}$ & $\begin{array}{l}-0.004 \\
(0.625)\end{array}$ \\
\hline D2001 & $\begin{array}{l}-0.032 \\
(0.000)\end{array}$ & $\begin{array}{c}0.038 \\
(0.000)\end{array}$ & $\begin{array}{l}-0.031 \\
(0.000)\end{array}$ \\
\hline D2002 & $\begin{array}{l}-0.036 \\
(0.000) \\
\end{array}$ & $\begin{array}{c}0.016 \\
(0.008) \\
\end{array}$ & $\begin{array}{l}-0.034 \\
(0.000) \\
\end{array}$ \\
\hline D2003 & $\begin{array}{l}-0,031 \\
(0.000)\end{array}$ & $\begin{array}{c}0.011 \\
(0.001)\end{array}$ & $\begin{array}{l}-0.030 \\
(0.025)\end{array}$ \\
\hline D2004 & $\begin{array}{l}-0.049 \\
(0.000)\end{array}$ & $\begin{array}{c}0.016 \\
(0.000)\end{array}$ & $\begin{array}{l}-0.049 \\
(0.003)\end{array}$ \\
\hline D2005 & $\begin{array}{l}-0.047 \\
(0.000) \\
\end{array}$ & $\begin{array}{c}-5.42 \mathrm{E}-04 \\
(0.848)\end{array}$ & $\begin{array}{l}-0.054 \\
(0.006) \\
\end{array}$ \\
\hline Sargan test & $\begin{array}{c}\chi^{2}(60)=76.558 \\
(0.073)\end{array}$ & $\begin{array}{l}\chi^{2}(50)=58.471 \\
(0.192)\end{array}$ & $\begin{array}{l}\chi^{2}(50)=54.971 \\
(0.292)\end{array}$ \\
\hline AR(1) test & $\begin{array}{l}-6.091 \\
(0.000)\end{array}$ & $\begin{array}{l}-5.541 \\
(0.000)\end{array}$ & $\begin{array}{l}-3.328 \\
(0.001)\end{array}$ \\
\hline$A R(2)$ test & $\begin{array}{l}-0.064 \\
(0.949)\end{array}$ & $\begin{array}{l}-0.442 \\
(0.659)\end{array}$ & $\begin{array}{l}-0.306 \\
(0.760)\end{array}$ \\
\hline
\end{tabular}

Note: $p$-values are indicated in parentheses 
Table 5

Joint significance tests

\begin{tabular}{|l|c|c|c|}
\hline \multirow{2}{*}{ Test } & \multicolumn{3}{|c|}{ Dependent variable: ENTRY } \\
\cline { 2 - 4 } & $\mathbf{p = 1}$ & $\mathbf{p = 2}$ & $\mathbf{p = 3}$ \\
\hline lag $\mathbf{p}$ & 24.170 & 1.360 & 1.190 \\
& $(0.000)$ & $(0.506)$ & $(0.552)$ \\
\hline joint signif past & 10.22 & 3.89 & 5.53 \\
entrycoefficients & $(0.001)$ & $(0.143)$ & $(0.137)$ \\
\hline joint signif past & 18.950 & 0.730 & 4.85 \\
exit coefficients & $(0.000)$ & $(0.694)$ & $(0.183)$ \\
\hline & \multicolumn{3}{|c|}{} \\
\hline Entry effect & 0.138 & 0.017 & 0.140 \\
(coef. sum) & $(0.001)$ & $(0.811)$ & $(0.225)$ \\
\hline Exit effect (coef. & 0.162 & 0.131 & 0.464 \\
sum) & $(0.000)$ & $(0.393)$ & $(0.032)$ \\
\hline & \multicolumn{3}{|c|}{ Dependent variable: EXIT } \\
\hline \multirow{2}{*}{ Test } & $\mathbf{p = 1}$ & $\mathbf{p = 2}$ & $\mathbf{p = 3}$ \\
\cline { 2 - 4 } & 7.900 & 0.340 & 2.000 \\
lag p & $(0.019)$ & $(0.844)$ & $(0.368)$ \\
\hline joint signif past & 2.190 & 2.790 & 1.920 \\
entry coef. & $(0.139)$ & $(0.248)$ & $(0.590)$ \\
\hline joint signif past & 6.70 & 2.81 & 2.02 \\
exit coef. & $(0.010)$ & $(0.245)$ & $(0.569)$ \\
\hline & \multicolumn{3}{|c|}{} \\
\hline Entry effect & 0.058 & 0.123 & 0.101 \\
(coef. sum) & $(0.139)$ & $(0.308)$ & $(0.577)$ \\
\hline Exit effect (coef. & 0.100 & 0.065 & 0.137 \\
sum) & $(0.010)$ & $(0.437)$ & $(0.412)$ \\
\hline Note: $p-V a l u e s$ are & & & \\
\hline & & & \\
\hline
\end{tabular}

Note: $p$-values are indicated in parentheses

The diagnostic tests are satisfactory in general in terms of non-rejection of the Sargan test for the validity of instruments and for the non-existence of second order serial correlation for the residuals. We limit the number of lags used as instruments, under predetermination of explanatory variables in each equation, so as not to weaken the Sargan test. The preferred model for the entry and exit equations is selected on joint significance tests to assess the maximum lag $p$ to be considered as reported in the first and sixth rows of Table 5 for entry and exit 
equations respectively. The evidence for both types of equations favours the choice of $p=1$ and with this result in mind one can proceed with a closer inspection of the entry and exit equations so as to assess interpretations in connection with the multiplier and competition effects.

Recall that we conclude for a competition effect where past exit (entry) rates positively influence future entry (exit) rates. Multiplier effects are present when entry and exit rates follow a positively autocorrelated structure (significant and positive lagged dependent variable coefficients).

The second and third rows of Table 5 test the significance of the entry and exit variables respectively. The fourth and fifth rows of table 5 present the total entry and exit effects respectively, by adding up the coefficients. These rows complement the significance tests and point to whether the effect of entry on entry is positive or negative.

In the selected lag structure (one lag), past entry influences entry and past exit influence entry, as both significance testes are rejected. Looking at the signs of these effects, we see that, for all lag choices, there seems to be a positive effect of past entry on current entry rates, albeit significant for the selected one lag length only. This is interpreted as a multiplier effect of entry on entry rates. On the other hand the positive, significant effect of past exit rates on current entry rates points to a competition effect from exit. Both multiplier and competition effects seem relevant for the dynamics of entry rates in Brazillian manufacturing.

The last five rows of Table 5 consider the exit rates equation. Again, lag choice tests point to the one lag regression, as in the entry equation. The next two rows evaluate the significance of entry and exit lags coefficients. The entry variable does not seem to influence exit rates, while exit rates follow an 
autoregressive pattern. The last line indicates that the autoregressive coefficient for exit is positive. This is interpreted as a multiplier effect of exit on exit rates.

Table 6 summarizes the main results in comparison with previous studies and indicates only partial conformity with earlier evidence. As mentioned, the multiplier effect seems to be present in both entry and exit equations whereas the competition effect emerges only in the case of the entry equation. Entry rates appear to have a similar pattern in Brazil and Sweden, while exit rates differ (only a multiplier effect of exit on exit rates was found).

Table 6

Comparison of empirical results with previous studies

\begin{tabular}{|c|c|c|c|c|}
\hline \multirow[t]{2}{*}{ Studies } & \multicolumn{2}{|c|}{ ENTRY (EN) } & \multicolumn{2}{|c|}{ EXIT (EX) } \\
\hline & $\partial \mathrm{EN}_{\mathrm{t}} / \partial \mathrm{EN}_{\mathrm{t}-1}$ & $\partial \mathrm{EN}_{\mathrm{t}} / \partial \mathrm{EX}_{\mathrm{t}-1}$ & $\partial \mathrm{EX}_{\mathrm{t}} / \partial \mathrm{EX} \mathrm{X}_{\mathrm{t}-1}$ & $\partial \mathrm{EX}_{\mathrm{t}} / \partial \mathrm{EN}_{\mathrm{t}-1}$ \\
\hline $\begin{array}{l}\text { Jonhson and } \\
\text { Parker (1994) }\end{array}$ & $\begin{array}{c}\text { competition } \\
\text { effect }\end{array}$ & $\begin{array}{c}\text { competition } \\
\text { effect }\end{array}$ & multiplier effect & multiplier effect \\
\hline $\begin{array}{l}\text { Kangasharju and } \\
\text { Moisio (1998) }\end{array}$ & not significant & multiplier effect & $\begin{array}{c}\text { competition } \\
\text { effect }\end{array}$ & not significant \\
\hline Nyström (2007) & multiplier effect & $\begin{array}{c}\text { competition } \\
\text { effect }\end{array}$ & $\begin{array}{c}\text { competition } \\
\text { effect }\end{array}$ & $\begin{array}{c}\text { competition } \\
\text { effect }\end{array}$ \\
\hline This study & multiplier effect & $\begin{array}{c}\text { competition } \\
\text { effect }\end{array}$ & multiplier effect & not significant \\
\hline
\end{tabular}

It is worth mentioning that this particular interpretation of the dynamic structure of entry and exit rates hinges on the selected lag structure $(p=1$ optimal lag). For the sake of robustness we considered multiplier and competition tests for other lag structures $(p=2$ and $p=3)$. In these cases the use of a sub-optimal lag structure would bias the results, as the non-significant lags would induce us not to reject the multiplier and competition effects.

\section{Final Comments}

The paper aimed to investigate the dynamic linkages between entry and exit rates in the context of the Brazilian manufacturing industry at the 4-digits level and 
using plant-level data. The evidence favours the prevalence of both multiplier and competition effects even after controlling for the business cycle and thus displays similarities with previous evidence for developed countries. However, contrasts emerge in the case of the exit equation where one only observes the multiplier effect with exit inducing further exit, which may possibly indicate the prevalence of significant network effects.

Avenues for future research include the assessment of specific underlying forces driving the multiplier and competition effects and the investigation, for example, of connections with productivity dynamics. Moreover, beyond the consideration of plant-level data it would be relevant to conduct the analysis at the firm level as well, but those initiatives are beyond the scope of the present paper. 


\section{References}

Agarwal, R., Gort, M. (1996) The Evolution of Markets and Entry, Exit and Survival of Firms, Review of Economics and Statistics, 78(3), 489-498

Arellano, M., Bond, S. (1991), Some tests of specification of panel data: Monte Carlo evidence and application to employment equations, Review of Economic Studies, 58, 277-297

Arauzo-Carod, J.M., Liviano-Solis, D., Manjón-Antolín, M.C. (2010), Empirical studies in industrial location: an assessment of their methods and results, Journal of Regional Science, 50, 685-711.

Armington, C., Acs, Z. (2002), The determinants of regional variation in new firm formation, Regional Studies, 36, 33-45

Baltagi, B.H. (2001), Econometric Analysis of Panel Data, New York: Wiley Baldwin, J.R., Gorecki, P.K. (1991), Firm entry and exit in the Canadian manufacturing sector, 1970-1982, Canadian Journal of Economics, 24, 300-323

Campbell, J.R. (1998), Entry, exit, embodied technology, and business cycles, Review of Economic Dynamics, 1, 371-408

Campos, N., lootty, M. (2007), Institutional barriers to entry: evidence from the Brazilian textiles and electronics industries, Economic Systems, 31, 346-363

Cameron. C., Trivedi, P. (2010), Microeconometrics: Methods and Applications Cambridge University Press, New York

Dejardin, M. (2004), Sectoral and cross-sectoral effects of retailing firm demographics, Annals of Regional Science, 38, 311-334

Disney, R., Haskel, J., Heden, Y. (2003), Entry, exit and establishment survival in UK manufacturing, Journal of Industrial Economics, 51, 91-112.

Dunne, T., Roberts, M.J., Samuelson, L. (1988), Patterns of Firm Entry and Exit in U.S. Manufacturing Industries, RAND Journal of Economics, 19, 495-515.

Dunne, T., Roberts, M.J. (1991), Variation in producer turnover across U.S. manufacturing industries, In P. Geroski and J. Schwalbach (eds.), Entry and Market Contestability: an International Comparison, Oxford: Blackwell 
Dunne, T., Klimek, S.D., Roberts, M.J., Xu, D.Y. (2011), Entry, exit and the determinants of market structure, Working paper, New York University.

Façanha, L.O., Resende, M. (2004), Dinâmica Multissetorial da Indústria Brasileira: um Estudo Empírico, Estudos Econômicos, 34, 693-723

Fritsch, M. (1997), New firms and regional employment change, Small Business Economics, 9, 437-448

Fritsch, M., Mueller, P. (2004), Effects of new business formation on regional development over time, Regional Studies, 38, 961-975

Geroski, P.A. (1991), Market Dynamics and Entry, Oxford: Blackwell Geroski, P.A. (1995), What do we know about entry?, International Journal of Industrial Organization, 13, 421-440

Geroski, P.A., Mata, J., Portugal, P. (2010) Founding conditions and the survival of new firms, Strategic Management Journal, 31, 510-529

Hopenhayn, H.A. (1992) Entry, exit, and firm dynamics in long run equilibrium, Econometrica, 60, 1127-1150.

Johnson, P., Parker, S. (1994), The Interrelationships between births and deaths, Small Business Economics, 6, 283-290

Johnson, P., Parker, S. (1996), Spatial variations in the determinants and effects of firm births and deaths, Regional Studies, 30, 679-688

Jovanovic, B., Lach, S. (1989) Entry, exit, and diffusion with learning by doing, American Economic Review, 79, 690-699

Kangasharju, A., Moisio, A. (1998), Births-deaths nexus of firms: estimating VAR with panel data, Small Business Economics, 11, 303-313

Klepper, S. (1996), Entry, exit, growth, and innovation over the product life cycle, American Economic Review, 86, 562-583

Manjon-Antolin, M. C. (2010). Firm size and short-term dynamics in aggregate entry and exit, International Journal of Industrial Organization, 28, 464-476. 
Manjón-Antolín, M.C., Arauzo-Carod, J.M. (2011) Locations and relocations:

determinants, modelling, and interrelations, Annals of Regional Science, 47, 131146.

Nyström, K. (2007), Interdependencies in the dynamics of entry and exit, Journal of Industry, Competition and Trade, 7, 113-130

Pakes, A., Ostrovsky, M., Berry, S. (2007), Simple estimators for parameters of discrete dynamic games (with entry/exit examples), RAND Journal of Economics, 38, 373-399

Resende, M. (2006), Profit persistence in Brazil: a panel data study, Estudos Econômicos, 36, 115-126

Shapiro, D., Khemani, R.S. (1987), The determinants of firm entry and entry, reconsidered, International Journal of Industrial Organization, 5, 15-26 